\title{
PENGARUH RISIKO KREDIT DAN RISIKO PASAR TERHADAP HARGA SAHAM PADA PERUSAHAAN PERBANKAN YANG TERDAFTAR DI INDONESIA STOCK EXCHANGE (IDX) PERIODE 2014-2016 Meti Zuliyana ${ }^{1)}$ William Arista Valendra ${ }^{2)}$
}

1)'Dosen jurusan Akuntansi, Universitas Tridinanti, Sumatera Selatan

2). Mahasisiwa jurusan Akuntansi, Universitas Tridinanti, Sumatera Selatan

${ }^{1)}$ Email: metizuliyana@gmail.com

\begin{tabular}{|c|c|}
\hline INFORMASI ARTIKEL & $A B S T R A K$ \\
\hline $\begin{array}{l}\text { Submitted: } \\
\text { 15/11/2021 } \\
\text { Revised: } \\
01 / 12 / 2021 \\
\text { Accepted: } \\
\text { 15/12/2021 } \\
\text { Online-Published: } \\
\text { 30/12/2021 }\end{array}$ & $\begin{array}{l}\text { Penelitian ini bertujuan untuk menguji dan mengetahui pengaruh NPL dan } \\
\text { NIM baik secara parsial maupun simultan terhadap harga saham perusahaan } \\
\text { perbankan yang terdaftar di Bursa Efek Indonesia tahun 2014-2016. Jenis } \\
\text { penelitian ini adalah penelitian kuantitatif dan jenis data yang digunakan } \\
\text { adalah data sekunder yang diperoleh peneliti secara tidak langsung dari objek } \\
\text { penelitian. Metode pengumpulan data yang digunakan adalah studi } \\
\text { dokumentasi.Variabel terikat yang digunakan adalah harga saham, sedangkan } \\
\text { variabel bebas yang digunakan adalah Net Performing Loan (NPL) dan Net } \\
\text { Interest Margin (NIM). Penelitian ini menggunakan analisis regresi linier } \\
\text { berganda karena analisis statistik dan model regresi telah diuji terlebih dahulu } \\
\text { dalam uji asumsi klasik.Hasil penelitian menunjukkan bahwa secara simultan } \\
\text { menunjukkan bahwa Net Performing Loan (NPL) dan Net Interest Margin } \\
\text { (NIM) berpengaruh signifikan terhadap harga saham. Hasil penelitian secara } \\
\text { parsial menunjukkan bahwa Net Performing Loan (NPL) dan Net Interest } \\
\text { Margin (NIM) berpengaruh signifikan terhadap harga saham. }\end{array}$ \\
\hline
\end{tabular}

Kata Kunci: Net Performing Loan, Net Interest Margin, Harga Saham

\begin{abstract}
Research this aims to examine and determine the effect of NPL and NIM both simultaneously and partially on the stock price of banking companies listed on the Indonesia Stock Exchange in 2014-2016. This type of research is quantitative research and the type of data used is secondary data obtained by researchers indirectly from the object of research. Data collection method used is documentation study.The dependent variable used is the stock price, while the independent variable used is the Net Performing Loan (NPL) and Net Interest Margin (NIM). This study uses multiple linear regression analysis for statistical analysis and regression models have been tested first in the classical assumption test.The results show that simultaneously shows that the Net Performing Loan (NPL) and Net Interest Margin (NIM) have a significant effect on stock prices. Partial research shows that the Net Performing Loan (NPL) and Net Interest Margin (NIM) have a significant effect on stock prices.
\end{abstract}

Keywords : Net Performing Loan, Net Interest Margin, Stock Price

\section{A. PENDAHULUAN}

Perusahaan perbankan merupakan salah satu lembaga keuangan yang berperan sebagai lembaga intermediasi yaitu lembaga yang berfungsi sebagai penyalur dana dari unit surplus ke unit defisit. Menurut Nuresya (2012) dalam Hendrayana dan yasa (2015) sebagai lembaga intermediasi antara pihakpihak yang memiliki kelebihan dana dengan pihak-pihak yang memerlukan dana, diperlukan bank dengan kinerja keuangan yang sehat sehingga fungsi intermediasi dapat berjalan dengan lancar. Menurut Undang-Undang No.10 tahun 1998, bank merupakan badan usaha yang menghimpun dana dari masyarakat dalam bentuk pinjaman dan menyalurkannya ke masyarakat dalam bentuk kredit dan/ atau bentuk-bentuk lainnya dalam rangka meningkatkan taraf hidup rakyat banyak. Mengingat peranan bank yang sangat penting, maka penilaian kinerja bank sangat berpengaruh terhadap 
kenyamanan dan kepercayaan calon nasabah. Semakin baik kinerja bank, maka akan semakin banyak para calon nasabah yang tertarik untuk menanamkan modalnya dan melaukan transaksi di bank tersebut.

Selain dari masyarakat sumber pendanaan bank di dapat dari saham yang diperjual belikan oleh Bank di Bursa Efek Indonesia. Menurut UU No.8 tahun 1995, pasar modal adalah pihak yang menyelenggarakan dan menyediakan sistem atau sarana untuk mempertemukan penawaran jual dan beli efek pihak-pihak lain dengan tujuan memperdagangkan efek diantara mereka. Perbankan dapat melakukan transaksi perdagangan saham di BEI karena salah satu tujuan bank adalah memperoleh profitabilitas yang maksimal dalam mengoptimalkan kegiatan operasional menurut Fahrul (2016). Perbankan Indonesia dalam menjalankan fungsinya berasaskan demokrasi ekonomi dan menggunakan prisnsip kehati-hatian. Fungsi utama perbankan Indonesia adalah sebagai penghimpun dan penyalur dana masyarakat serta bertujuan untuk menunjang pelaksanaan pembangunan nasional dalam rangka meningkatkan pemerataan pembangunan dan hasil-hasilnya, pertumbuhan ekonomi dan stabilitas nasional, kearah peningkatan taraf hidup rakyat banyak (Booklet Perbankan Indonesia 2008).

Bank merupakan industri yang dalam kegiatan usahanya mengandalkan kepercayaan masyarakat dalam menghimpun atau menggola dana sehingga menjadi penting bagi calon investor dan masyarakat untuk mengetahui kinerja dan tingkat risiko suatu bank sebelum melakukan investasi dan mempercayakan dananya untuk dikelola oleh bank tersebut. Salah satu risiko yang wajib diperhatikan oleh calon investor adalah risiko kredit dan risiko pasar, salah satu contoh bank yang tidak mampu mengelola risiko kreditnya adalah Bank Bukopin.

Pada tahun 2017 tingkat kredit bermasalah BBKP mencapai $6,37 \%$ atau meningkat hampir 128\% dibandingkan NPL tahun 2016 yaitu sebesar $2,79 \%$. Salah satu penyumbang terbesar kenaikan tingkat NPL adalah sektor pertambangan. Hal ini disebabkan oleh penurunan harga komoditas pertambangan seperti batu bara dan sawit. Salah satu akibat dari tingginya tingkat NPL PT. BUKOPIN,
TBK adalah turunya harga saham di tahun 2017 sebesar 590 dari harga saham di tahun 2016 sebesar 640.

Peranan kredit dalam operasi bank sangat besar dan penting karena sebagian besar bank masih mengandalkan sumber pendapatan utamanya dari bisnis pengkreditan. Berdasarkan Surat Edaran Bank Indonesia No.13/24/DPNP tanggal 25 Oktober 2011. Risiko kredit adalah risiko akibat kegagalan debitur atau pihak lain dalam memenuhi kewajiban kepada bank. Menurut Hernan (2011:16), semakin tinggi risiko kredit dari ketidak lancaran pembayaran pokok pinjaman dan bunga maka secara langsung akan berdampak pada penurunan kinerja perbankan. Risiko kredit dapat diukur menggunakan Non Performing Loan (NPL).

Non Performing Loan (NPL) adalah perbandingan antara total kredit bermasalah dengan total kredit yang diberikan kepada debitur. Menurut peraturan Bank Indonesia No.13/3/PBI/2011 menetapkan rasio NPL maksimal 5\% dari total kredit. Apabila rasio NPL dibawah 5\% menunjukkan bahwa bank dapat mengelola risiko kreditnya dengan baik karena mampu meminimalkan kreditnya sehingga dapat berdampak baik pada penilaian kinerja keuangan bank.

Menurut Veithzal $(2013,569)$ risiko pasar merupakan risiko yang timbul karena adanya pergerakan variabel pasar dari protofolio yang dimiliki oleh bank yang dapat merugikan bank (Adverse Movement). Salah satu proksi dari risiko pasar adalah suku bunga, yang diukur dari selisih antara suku bunga pendanaan (funding) dengan suku bunga pinjaman yang diberikan (lending) atau dalam istilah perbankan disebut Net Interest Margin (NIM).

Net Interest Margin (NIM) digunakan untuk mengukur kemampuan manajemen bank dalam menghasilkan pendapatan dari bunga dengan melihat kinerja bank dalam menyalurkan kredit. Mengingat pendapatan operasional bank sangat tergantung dari selisih bunga dari kredit yang disalurkan. Standar yang ditetapkan Bank Indonesia untuk rasio NIM adalah 6\% keatas. Semakin besar NIM yang dicapai oleh suatu bank maka akan meningkatkan pendapatan bunga atas asset produktif yang dikelola oleh bank yang bersangkutan. Sehingga laba bank 
(ROA) akan meningkat yang berdampak pada semakin baiknya kinerja keuangan perbankan.

Risiko pasar menurut Peraturan Bank Indonesia Nomor 11/25/PBI/2009 tentang Perubahan Atas Peraturan Bank Indonesia Nomor 5/8/PBI/2003 tentang Penerapan Manajemen Risiko Bagi Bank Umum, adalah risiko pada posisi neraca dan rekening administratif termasuk transaksi derivative, akibat perubahan secara keseluruhan dari kondisi pasar, termasuk risiko perubahan harga option. Risiko pasar meliputi antara lain risiko suku bunga, risiko nilai tukar, risiko komoditas, serta risiko ekuitas.

Risiko pasar muncul karena harga pasar bergerak dalam arah yang merugikan organisasi. Misalnya, suatu perusahaan mempunyai portofolio sekuritas saham yang dibeli dengan harga Rp 1 miliar. Misalkan harga saham jatuh, sehingga nilai pasar saham tersebut turun menjadi Rp 800 juta. Perusahaan tersebut mengalami kerugian karena nilai portofolio sahamnya turun sebesar Rp 200 juta. Kerugian tersebut disebabkan karena harga saham bergerak kearah yang kurang menguntungkan (dalam hal ini turun).

Berdasarkan uraian latar belakang diatas maka penulis tertarik untuk melakukan penelitian dengan judul "Pengaruh Risiko Kredit (Non Performing Loan) Dan Risiko Pasar (Net Interest Margin) Terhadap Harga Saham Pada Perusahaan Perbankan Yang Terdaftar Di Indonesia Stock Exchange (IDX) Periode Tahun 2014-2016".

Berdasarkan uraian latar belakang yang telah dikemukakan diatas, maka identifikasi masalah dalam penelitian ini adalah:

1. Berapa besar pengaruh resiko kredit dan risiko pasar secara parsial terhadap harga saham pada perusahaan perbankan yang terdaftar di Indonesia Stock Exchange (IDX) ?

2. Berapa besar pengaruh risiko kredit dan risiko pasar secara simultan terhadap harga saham pada perusahaan perbankan yang terdaftar di Indonesia Stock Exchange (IDX)?

Sehubungan dengan identifikasi masalah yang telah dikemukakan sebelumnya, maka penelitian ini bertujuan untuk:
1. Untuk mengetahui dan menganalisa risiko kredit dan risiko pasar secara parsial terhadap harga saham pada perusahaan perbankan yang terdaftar di Indonesia Stock Exchange (IDX) ?

2. Untuk mengetahui dan menganalisa risiko kredit dan risiko pasar secara simultan terhadap harga saham pada perusahaan perbankan yang terdaftar di Indonesia Stock Exchange (IDX) ?

\section{- Risiko Kredit}

Berdasarkan Surat Edaran Bank Indonesia No. 13/24/DPNP tanggal 25 Oktober 2011, risiko kredit adalah risiko akibat kegagalan debitur dan/atau pihak lain dalam memenuhi kewajiban kepada bank. Risiko kredit pada umumnya terdapat pada seluruh aktivitas bank yang kinerjanya bergantung pada kinerja pihak lawan (counterparty), penerbit (issuer) atau kinerja peminjam dana (borrower). Risiko kredit juga dapat diakibatkan oleh terkonsentrasinya penyediaan dana pada debitur, wilayah geografis, produk, jenis pembiayaan, atau lapangan usaha tertentu. Risiko kredit menurut Darmawi (2011:16) Risiko kredit adalah memberikan kredit kepada nasabahnya. Pemberian kredit yang sehat berimplikasi pada kelancaran pengambilan kredit oleh nasabah atas pokok pinjaman atau beban bunga. Ketidak lancaran pembayaran pokok pinjaman dan bunga secara langsung dapat menurunkan kinerja bank.

\section{- Risiko Pasar}

Berdasarkan Surat Edaran Bank Indonesia No. 13/24/DPNP tanggal 25 Oktober 2011, risiko pasar adalah risiko pada posisi neraca dan rekening administratif termasuk transaksi derivative, akibat perubahan kondisi pasar, termasuk risiko perubahan harga option. Risiko pasar meliputi antara lain risiko suku bunga, risiko nilai tukar, risiko komoditas, serta risiko ekuitas. Risiko merupakan besarnya penyimpangan antara tingkat pengembalian yang diharapkan dengan tingkat pengembalian actual. Investor dalam menjalankan aktivitas investasinya dihadapkan oleh 2 macam risiko, yaitu risiko tidak sistematis dan risiko sistematis (Jogiyanto, 2000). Risiko tidak sistematis berkaitan dengan kejadian khusus yang terjadi pada suatu perusahaan tertentu, seperti pemogokan, program pemasaran yang gagal, 
pergantian kepemimpinan, dan sebagainya. Karena kejadian tersebut pada dasasrnya bersifat acak, maka risiko dapat dihilangkan dengan cara diversifikasi. Risiko tidak sistematis perusahaan tidak berkorelasi dengan perusahaan lainnya (Haruman, 2005). Sedangkan risiko sistematis adalah risiko sekuritas yang tidak dapat dihilangkan. Umumnya berasal dari faktor yang secara sistematik mempengaruhi perusahaan, seperti inflasi, nilai mata uang, dan suku bunga. Risiko sistematis disebut juga risiko pasar (market risk), karena dampaknya mempengaruhi semua saham. Risiko pasar adalah risiko yang dihadapi suatu sekuritas yang disebabkan oleh faktor-faktor pasar, seperti faktor ekonomi, politik, dan sebagainya (Tandelilin,2001).

\section{- Harga Saham}

Menurut Martalena, dkk (2011) dalam Sofiani (2013) harga saham adalah nilai suatu saham yang ditentukan oleh permintaan dan penawaran yang terbentuk di bursa saham. Menurut Husnan, dkk (2004) dalam Rudy (2013) mendefinisikan saham atau sekuritas merupakan secarik kertas yang menunjukan hak pemilik kertas tersebut untuk memperoleh bagian dari prospek atau kekayaan perusahaan yang menerbitkan sekuritas tersebut. Selembar saham mempunyai nilai atau harga yang dapat dibedakan menjadi tiga yaitu :

1. Saham Nominal.

2. Harga Perdana.

3. Harga Pasar.

Dalam menilai harga saham terdapat tiga pedoman yeng dipergunakan. Pertama, bila harga saham melampaui nilai intrinsik saham, maka saham tersebut dinilai overvalued (harganya terlampau tinggi). Kedua, harga saham sama dengan nilai intrinsiknya maka harga saham tersebut dinilai wajar dan berada dalam konsisi aman. Ketiga, apabila harga saham lebih kecil dari nilai intrinsiknya maka saham tersebut dikatan undervalued (harganya terlalu rendah).

Berdasarkan uraian kerangka berfikir di atas dapat disajikan alur kerangka pemikiran yang dapat dilihat pada Gambar 1.

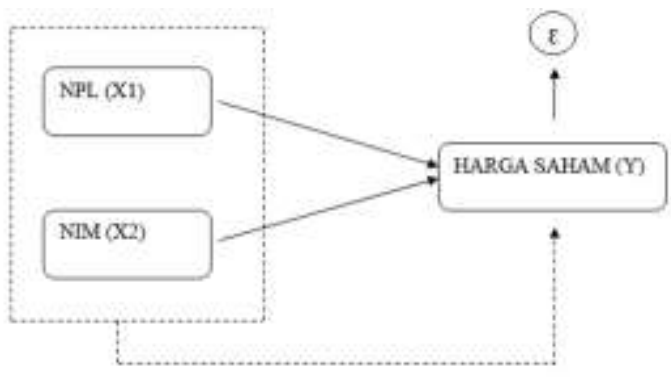

Gambar 1. Kerangka Berfikir

Keterangan :

$\longrightarrow \quad$ :Pengaruh secara Simultan

$\longrightarrow \quad$ : Pengaruh secara Parsial

$\varepsilon \quad:$ Standar error

Hipotesis dalam penelitian ini adalah :

1. Diduga risiko kredit dan risiko pasar pengaruh secara parsial terhadap harga saham pada perusahaan perbankan yang terdaftar di Indonesia Stock Exchange (IDX).

2. Diduga risiko kredit dan risiko pasar pengaruh secara simultan terhadap harga saham pada perusahaan perbankan yang terdaftar di Indonesia Stock Exchange (IDX).

\section{B. METODE PENELITIAN}

Penelitian ini dilakukan pada perusahaan Perbankan yang terdaftar di Indonesia Stock Exchange (IDX) pada website www.idx.co.id. Dalam penelitian ini penulis menggunakan data sekunder. Data sekunder yang digunakan dalam penelitian ini terdiri dari data keuangan perusahaan yang diperoleh dari laporan tahunan perusahaan Perbankan tahun 2014-2016 yang di unduh dari website resmi (http://www.idx.co.id). Dalam penelitian ini, peneliti menggunakan data dokumentasi dalam melakukan penelitian ini adalah berupa laporan keuangan serta informasi-informasi yang didapat dari masing-masing Perusahaan Perbankan yang terdaftar di Indonesia Stock Exchange (IDX). Sampel dalam penelitian ini adalah perusahaan Perbankan yang terdaftar di IDX dari tahun 2014 - 2016 yang memenuhi kriteria sampel penelitian ini . Adapun kriteria sampel dalam penelitian ini yaitu perusahaan Perbankan yang memiliki laporan keuangan lengkap dari tahun 20142016. Ada 43 perusahaan Perbankan yang terdaftar di Indonesia Stock Exchange (IDX) 
tahun 2016. Dari 43 perusahaan ini hanya ada 39 perusahaan yang memenuhi kriteria menjadi sampel dalam penelitian ini. Hal ini dikarenakan 4 perusahaan lainnya tidak memiliki laporan keuangan yang lengkap selama 3 (tiga) tahun terakhir 2014-2016.

Variabel dalam penelitian ini adalah Variabel independen $(\mathrm{X})$ : X1 Non Performing Loan (NPL), X2 Net Interest Margin (NIM). Variabel dependen (Y): Y (Harga Saham). Uji statistik menggunakan Regresi Linier Berganda yang sebelumnya harus menggunakan uji asumsi klasik, apabila sudah memenuhi syarat maka dilanjutkan dengan Regresi Linier Berganda. Pengujian hipotesis Uji Koefisien Regresi Secara Parsial (Uji t) dan Uji Koefisien Regresi Secara Bersama-sama (Uji F), Analisis Korelasi Ganda, dan Uji Koefisien Determinasi (R2).

\section{HASIL DAN PEMBAHASAN}

- Analisis Risiko Kredit (Net Performing Loan) Dan Risiko Pasar (Net Interest Margin) Secara Parsial Terhadap Harga Saham Pada Perusahaan Perbankan Yang Terdaftar Di Indonesia Stock Exchange (IDX) Periode Tahun 2014-2016".

Pada Tabel 1 dapat dilihat hasil pengujian hipotesis secara parsial yang telah dilakukan dengan menggunakan SPSS Versi 22.0, adalah sebagai berikut:

Tabel 1. Hasil pengujian hipotesis secara parsial

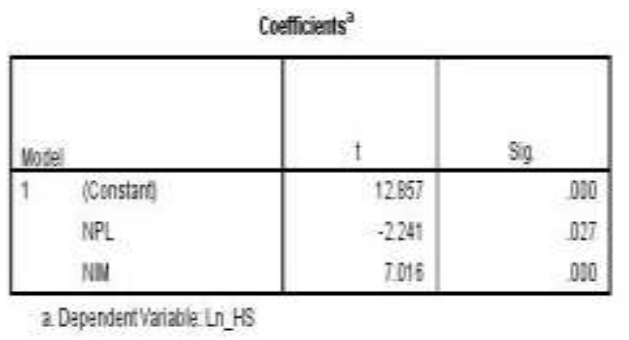

Sumber: data diolah, pada tahun 2018

Dapat dilihat bahwa koefisien NPL bernilai negatif sebesar -2,241 dan nilai ttabel sebesar $-1,981$, sehingga diperoleh -thitung < -ttabel yaitu $-2,241<1,981$, dengan signifikansi $0,027<0,05$. Hal ini berarti bahwa NPL berpengaruh negatif dan signifikan terhadap harga saham. NIM bernilai positif sebesar 7,016 dan nilai ttabel sebesar 1,981, sehingga diperoleh thitung > ttabel yaitu 7,016> 1,981 , dengan signifikansi $0,000<0,05$. Hal ini berarti bahwa NIM berpengaruh positif dan signifikan terhadap harga saham.

- Analisis Risiko Kredit (Net Performing Loan) Dan Risiko Pasar (Net Interest Margin) Secara Simultan Terhadap Harga Saham Pada Perusahaan Perbankan Yang Terdaftar Di Indonesia Stock Exchange (IDX) Periode Tahun 2014-2016".

Pada Tabel 2 dapat dilihat hasil pengujian hipotesis secara simultan yang telah dilakukan dengan menggunakan SPSS Versi 22.0, adalah sebagai berikut:

Tabel 2. Hasil pengujian hipotesis secara simultan

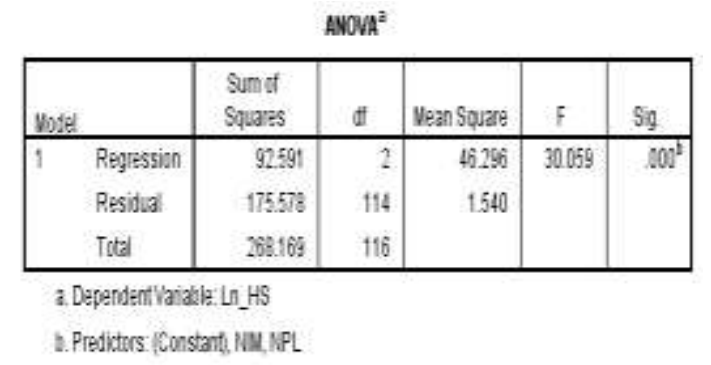

Sumber: data diolah, pada tahun 2018

Penelitian ini membuktikan bahwa NPL (Net Performing Loan) dan NIM (Net Interest Margin) mampu mempengaruhi harga saham diperoleh nilai Fhitung sebesar 30,059 lebih besar dari Ftabel $(3,076)$, hal ini juga diperkuat dengan nilai taraf signifikansi sebesar 0,000 atau signifikansi yang diperoleh lebih kecil dari $\alpha=0,05$, maka dapat disimpulkan bahwa NPL dan NIM secara bersama-sama berpengaruh positif dan signifikan terhadap harga saham pada perusahaan Perbankan yang terdaftar di Indonesia Stock Exchange (IDX). Untuk Ajusted R Square sebesar 0,334. Jumlah tersebut memiliki arti bahwa variabel NPL dan NIM mampu mempengaruhi harga saham sebesar $33,4 \%$, sedangkan sisanya sebesar $66,6 \%$ dipengaruhi oleh faktor lain di luar model ini. Dapat dilihat pada Tabel 3. 
Tabel 3. Nama Tabel Uji Koefisien Determinasi $\left(\mathbf{R}^{2}\right)$

Output Uji Koefisien Determinasi $\left(\mathrm{R}^{2}\right)$

Model Summary

\begin{tabular}{|l|c|r|r|r|}
\hline Model & $R$ & $R$ Square & $\begin{array}{c}\text { Adjusted } R \\
\text { Square }\end{array}$ & $\begin{array}{c}\text { Std. Error of } \\
\text { the Estimate }\end{array}$ \\
\hline 1 & $.588^{\mathrm{a}}$ & .345 & .334 & 1.24103 \\
\hline
\end{tabular}

a. Predictors: (Constant), NIM, NPL

Sumber: data diolah, pada tahun 2018

\section{SIMPULAN DAN SARAN}

\section{Simpulan}

1. Variabel Net Performing Loan (NPL) dinyatakan secara parsial berpengaruh negatif dan signifikan terhadap harga saham. Hal ini ditunjukkan dengan nilai thitung sebesar $-2,241$ yang artinya thitung < -ttabel $(-2,241<1,981)$ dengan tingkat pengaruh signifikan NPL terhadap harga saham kurang dari 5\% $(0,027<$ 0,050). Variabel Net Interest Margin (NIM), secara parsial berpengaruh positif dan signifikan terhadap harga saham. Hal ini ditunjukkan dengan nilai thitung sebesar 7.016 yaitu artinya thitung $>$ ttabel (7.016 > 1,981) dengan tingkat pengaruh signifikan NIM terhadap harga saham kurang dari $5 \%(0,000<0,050)$.

2. Variabel independen yaitu Net Performing Loan (NPL) dan Net Interest margin (NIM) secara simultan berpengaruh dan signifikan terhadap harga saham. Ini berarti rasio yang diuji mempengaruhi perubahan harga saham. Hasil Uji (R2) sebesar 0,334 atau 33,4\% artinya variabel independen mampu menjelaskan variabel dependen sebesar $33,4 \%$, sisanya sebesar $66,6 \%$ (100\%-33,4\%) dijelaskan oleh variabel lain yang tidak diteliti dalam penelitian.

\section{Saran}

1. Bagi Perusahaan

Penelitian mengenai harga saham ini hanya terbatas pada informasi internal masing-masing perusahaan. Oleh karena itu disarankan untuk memperhatikan faktor lain yang juga mempengaruhi harga saham disamping faktor internal perusahaan seperti tingkat pendapatan bunga, suku bunga, dan nilai tukar.
2. Bagi Investor

Untuk investor harus lebih memperhatikan atau melakukan analisis terlebih dahulu terhadap calon perusahaan, baik dari segi rasio-rasio keuangan diluar dari penelitian ini.

3. Bagi peneliti selanjutnya

Disarankan untuk mengembangkan penelitian ini dengan cara memperpanjang periode penelitian atau menambah variabel independen seperti: CR (Current Ratio), ROE (Return On Equity) dll, yang masih berbasis pada data laporan keuangan dengan tetap berlandaskan pada penelitian sebelumnya.

\section{E. DAFTAR RUJUKAN}

Buku:

Arief Sugiono dan Edy Untung, 2016, Panduan Praktis Dasar Analisa Laporan Keuangan, PT Grasindo, Jakarta.

Darmadji, Tjiptono dan Hendy M. Fakhruddin. 2011. Pasar Modal di Indonesia. Jakarta: Salemba Empat.

Fakhruddin, Hendi. 2008. Isitilah Pasar Modal A-Z. Jakarta: Elex Media Komputindo.

Ghozali. Imam, 2006. Analisis Multivariate dengan program SPSS. Edisi ke-4. Badan Penerbit Universitas Diponegoro: Semarang.

H. Veithzal Rivai, 2013. Buku Commercial Bank Management : Manajemen Perbankan Dari Teori Ke Praktik, Edisi 1, Rajawali Pers. Jakarta.

Ikatan Bankir Indonesia, 2016. Bisnis Kredit Perbankan, PT Gramedia Pustaka Utama, Jakarta.

Kasmir, 2012, Analisis Laporan Keuangan, Rajawali Pers, Jakarta.

2014, Dasar-Dasar Perbankan, PT

Raja Grafindo Persada, Jakarta.

, 2014, Bank dan Lembaga Keuangan Lainnya, PT Raja Grafindo Persada, Jakarta.

Peraturan Bank Indonesia Nomor : 13/1/PBI/2011.

Sugiyono, 2011, Metode Penelitian Kuantitatif, Kualitatif, dan R\&D, Alfabeta, Bandung.

Surat Edaran Bank Indonesia No. 6/23/DPNP/2004. 
Jurnal Kompetitif, Vol. 10, No. 2, hal. 01 - 07, Juli - Desember 2021

p-ISSN 2302-4585; e-ISSN 2721-3765

Undang-undang Republik Indonesia Nomor 10 Tahun 1998.

V. Wiratna, Sujarweni, 2014, Metodologi Penelitian, Pustaka Baru Press, Yogyakarta.

Widioatmodjo, Sariwidji. 2012. Cara Cepat Memulai Investasi Saham Panduan Bagi Pemula. Jakarta: PT Elex Media Komputindo.

Website:

www.idx.co.id

www.sahamok.com

www.britama.com

www.duniainvestasi.com 